\title{
Community Application
}

Prof. Geetha Chillarge ${ }^{1}$, Akshita Shinde ${ }^{2}$, Anuj Padmawar ${ }^{2}$, Neha Kolekar ${ }^{2}$, Pradyumna Deshpande ${ }^{2}$

${ }^{1}$ MTech (Computer Network Engineering), Ph.D. (Pursuing), Department of Computer Engineering, SPPU/MMCOE, Pune, Maharashtra, India

${ }^{2}$ Department of Computer Engineering, SPPU/MMCOE, Pune, Maharashtra, India

\begin{abstract}
Article Info

Volume 7, Issue 3

Page Number: 37-43

Publication Issue :

May-June-2021

\section{Article History}

Accepted : 01 May 2021

Published : 05 May 2021

Community development is basically the task wherein people belonging to a particular community come together and help in strengthening the civil society by categorising the actions of their respective communities, and their perspectives in building an economic, social and environmental approach. The community development workers help communities to bring about the required social change, thus improving the quality of life in their stipulated areas. Nowadays, online applications have become a vital component of any industry. Businesses can now be grown effortlessly and have become easier by using web applications and also in achieving the goals in a minimal span of time. The evolution of any web application involves the identification of product requirements, plotting, coding, and examining using the required technologies and frameworks. The applications are built on top of frameworks so that the elementary requirements in the development activity of the web applications are already initiated and can be fulfilled accordingly.

Keywords : Model View Controller (MVC), Model View Template, Framework, Web Server Application Development, Document Object Model, Python Packet manager, Content management system
\end{abstract}

\section{INTRODUCTION}

A community development platform is an online margin constructed by an institution or a firm, wherein the community members, customers and fans alike can come together, interrogate, get peer-topeer support, take about interests encircling the brand and make social associations. It is indispensably a home for you to house your inner communities. An intermediate space where the audience and customers can share their plans, experiences, tips and create connections over mutual engrossments, and can support your community. The idea for community building platforms has gathered a commendable amount of contemplation since the past few years, specifically for providing customer experience. It has now become an essential for many organizations. In general, the drastically growing customer engagement through enhanced customer experience has become one of the major business

Copyright: @ the author(s), publisher and licensee Technoscience Academy. This is an open-access article distributed under the terms of the Creative Commons Attribution Non-Commercial License, which permits unrestricted non-commercial use, distribution, and reproduction in any medium, provided the original work is properly cited 
priorities and a community building platform is one of the most powerful ways to achieve it. The community is an asset for many customers. A place where they can discover a huge source of information, questions and answers to it quickly. They can bounce off each other's ideas and work through problems in unison. They can unite with new people having similar passions and interests. Many people at times go to communities to get the feeling of acceptance and nerd out over interests.

For a number of people these days, communities may give a feeling of homeliness that consists of a "family of invisible friends", in addition to which these 'friends' can be connected via gaming gangs and gaming circles. All those who are willing to get into an online community have to initially become a member through a specific site and can therefore get direct access to the specific content or links. But in today's mankind and providence where media life has been entirely blended into the average day; the online community has stemmed to a full-fledged culture. Also, the community can function as an information system where the members can post, share their opinions based on discussions, give suggestions or collaborate, and comprise medical advice or any specific health related care research.

\section{LITERATURE SURVEY}

\begin{tabular}{|c|c|c|}
\hline Title of Paper & Advantages & Limitations \\
\hline $\begin{array}{l}\text { Full-stack web development using } \\
\text { Django REST } \\
\text { framework and React. (Vainikka, } \\
\text { 2018) }\end{array}$ & $\begin{array}{l}\text { - The goal of this project was to create a more } \\
\text { flexible and scalable system with RESTful } \\
\text { API, which can operate on desktop web } \\
\text { browsers and mobile } \\
\text { devices. } \\
\text { - By default, Django ships with a } \\
\text { development server and an admin panel, } \\
\text { which gives a good starting point for a } \\
\text { project. Setting up a RESTful API was } \\
\text { effortless, } \\
\text { and the created Django model transformed } \\
\text { well into an API. }\end{array}$ & $\begin{array}{l}\text { - The project itself did not get } \\
\text { far enough for the possible } \\
\text { conflicts to say if there are some } \\
\text { structural problems in the } \\
\text { system. For this reason, the } \\
\text { problems } \\
\text { mainly were about time and } \\
\text { project management. }\end{array}$ \\
\hline $\begin{array}{l}\text { Review Paper on Web } \\
\text { Frameworks, Databases and Web } \\
\text { Stacks. (Jyoti Shetty, 2020) }{ }^{2}\end{array}$ & $\begin{array}{l}\text {-The choosing of web } \\
\text { stack should be done based on few critical } \\
\text { factors like time } \\
\text { needed to take the product to market, long } \\
\text { term scalability } \\
\text { and maintenance, ease of programming, } \\
\text { developer's } \\
\text { proficiency with the technologies etc. All } \\
\text { these factors are important } \\
\text { while building modern web applications. }\end{array}$ & $\begin{array}{l}\text { - Critical factors such as } \\
\text { efficiency should be considered }\end{array}$ \\
\hline
\end{tabular}


Prof. Geetha Chillarge et al Int. J. Sci. Res. Comput. Sci. Eng. Inf. Technol, May-June - 2021, 7 (3) : 37-43

\begin{tabular}{|c|c|c|}
\hline $\begin{array}{l}\text { Creating a web application with } \\
\text { react native. (Siddegowda C J, } \\
2018 \text { ) }\end{array}$ & $\begin{array}{l}\text {-React and other similar JavaScript } \\
\text { libraries ease the development of } \\
\text { snappy, event-driven user } \\
\text { interfaces that are fast at } \\
\text { responding to state changes. } \\
\text { - One underlying goal can be } \\
\text { identified in the } \\
\text { desire to bridge the gap between } \\
\text { web apps and native apps: users } \\
\text { expect web apps to feel smooth and } \\
\text { seamless like native applications. }\end{array}$ & $\begin{array}{l}\text {-The manual installation process } \\
\text { has to be used when we want to } \\
\text { use react. }\end{array}$ \\
\hline $\begin{array}{l}\text { Managing user data of the web } \\
\text { application for computer- } \\
\text { Based testing academic } \\
\text { performance of the students. } \\
\text { (Парфьонов, 2019) }\end{array}$ & $\begin{array}{l}\text {-The results can be applied in the } \\
\text { development of } \\
\text { user management subsystems for } \\
\text { Django-based web } \\
\text { applications with several types of } \\
\text { users when the profile } \\
\text { of each of them must be } \\
\text { dynamically selected in the } \\
\text { application runtime. }\end{array}$ & $\begin{array}{l}\text {-This does not include a high level } \\
\text { of security. }\end{array}$ \\
\hline
\end{tabular}


Prof. Geetha Chillarge et al Int. J. Sci. Res. Comput. Sci. Eng. Inf. Technol, May-June - 2021, 7 (3) : 37-43

\begin{tabular}{|c|c|c|}
\hline $\begin{array}{l}\text { Python Libraries and Packages for } \\
\text { Web Development-A } \\
\text { Survey. (S.L. Kavya, 2019) }\end{array}$ & $\begin{array}{l}\text {-This survey paper comprises } \\
\text { various python libraries and } \\
\text { modules that have been used in } \\
\text { web development. } \\
\text { •Build more functions with fewer } \\
\text { lines of code. Python is great for } \\
\text { backend web development, data } \\
\text { Analysis and AI. }\end{array}$ & $\begin{array}{l}\text {-This does not have front end } \\
\text { requirements needed for this } \\
\text { project. }\end{array}$ \\
\hline $\begin{array}{l}\text { Django the python web } \\
\text { Framework. (Prof. B Nithya } \\
\text { Ramesh, 2019) }\end{array}$ & $\begin{array}{l}\text {-This article gives an overview of } \\
\text { why to choose Django over any } \\
\text { other framework. Django is a high- } \\
\text { level Python framework by using it } \\
\text { the development speed will be } \\
\text { faster and cleaner. } \\
\text { - Django is built by much more } \\
\text { experienced people, is also open } \\
\text { source and free and it follows the } \\
\text { principle of "Don't Repeat } \\
\text { Yourself". } \\
\text { CSRF usage Statistics }\end{array}$ & $\begin{array}{l}\text {-This paper contains all python and } \\
\text { django topics but does not include } \\
\text { the web design integration theory. }\end{array}$ \\
\hline
\end{tabular}




\begin{tabular}{|c|c|c|}
\hline $\begin{array}{l}\text { Using Firebase Cloud Messaging to } \\
\text { Control Mobile Applications. } \\
\text { (Mohamed Abdalla Mokar, 2019) }\end{array}$ & $\begin{array}{l}\text { 'we get some result that is the } \\
\text { proposed system can help the } \\
\text { developers to send update faster to } \\
\text { mobile application using FCM with } \\
\text { efficient and less effort and Some } \\
\text { recommendations have been made } \\
\text { to improve the proposed system in } \\
\text { the future where it is preferred to } \\
\text { save these commands directly } \\
\text { without needing to apply this Data } \\
\text { from the user, and save this data } \\
\text { directly when notification is } \\
\text { received in the mobile app. }\end{array}$ & $\begin{array}{l}\text {-It only tells us about the use of } \\
\text { firebase. Firebase will be used for } \\
\text { deployment of websites. }\end{array}$ \\
\hline
\end{tabular}

\section{METHODS AND MATERIAL}

An easy way to comply with the conference paper formatting requirements is to use this document as a

\section{A. System Architecture}

Web application architecture defines the interactions between applications, middleware systems and databases to ensure multiple applications can work together. Software architecture of a system describes its major components, their relationships, and how they interact with each other.

In the proposed architecture, the website will be able to provide a platform for creating a community and will let the admin handle it throughout its lifecycle. In later stages by using AI technology user insights, user classification and recommendation systems will be integrated. The user interface will allow you to register into the system. Here we have provided users with an interactive user interface. At the time of registration, a user can give details about his interest and in which type of community he/she is interested in. depending on that the user will be grouped into respective groups.

After verifying the account details a user can look at the things he is interested in. for example, if user has selected the alumni student then he can see job recommendations, contact details of other teachers and courses and updates about other students if he clicks on the user profile. We are proposing a system in which users can then contact the teacher for help related to jobs or projects and he/she can apply for a job. The admin is the person who has authority to verify the persons details and add him into the 
community.

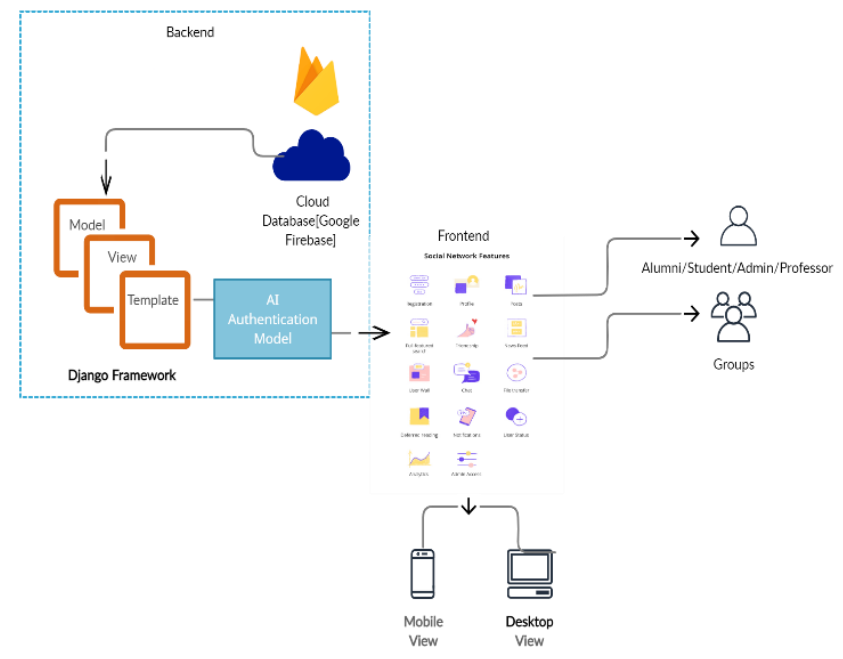

Fig 1.1 Architecture diagram

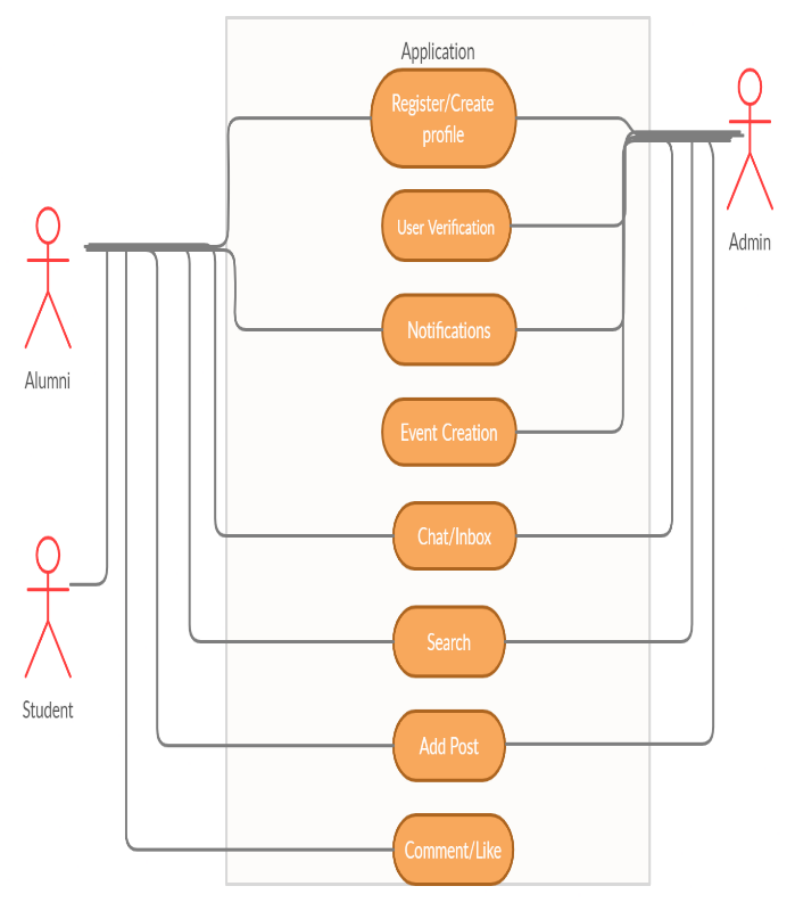

Fig 1.2 Use case diagram

The above diagram shows the user flow of the application. Student will loin through his credentials and he will be able to see the options like notification, chat, search, add post, job posts and if he/she is admin then he will see options like event creation, user verification

\section{B. Tools and technologies}

Django

\section{- Firebase \\ - Bootstrap}

\section{RESULTS AND DISCUSSION}

The proposed system can hence be used for connecting people having similar fields of interests with each other. This user interface helps users to connect with each other smoothly and contact each other for any further help if required. User validation can be done with the help of One Time Passwords in future work. Thus, community development will mould people to become more responsible, inherit healthy ways of living and provide economic opportunities. Our application would be useful in various areas like alumni communication platforms to begin with and entrepreneurship opportunity programmes as we proceed.

\section{A. Automatic Document Verification}

The document should be verified automatically when a user is registered.

\section{B. Report Generation}

User insights reports will be generated using AI technology.

\section{AI enabled Validation}

Login process is validated for everyone (user, admin, super admin) using AI based algorithm(s)

\section{Chatbot Efficiency}

Chatbot solves the received queries efficiently and gives relevant and to-the-point feedback.

\section{E. Reactive User Interface}

Reactive interface helps users to understand the functions of different buttons and labels.

\section{CONCLUSION}

Although a conclusion may review the main points of the paper, do not replicate the abstract as the conclusion. A conclusion might elaborate on the 
importance of the work or suggest applications and extensions. Authors are strongly encouraged not to call out multiple figures or tables in the conclusion these should be referenced in the body of the paper.

\section{REFERENCES}

[1]. Joel Vainikka, "Full-stack web development using Django REST framework and React". 2018. Metropolia University of Applied Sciences. (16 May 2018)

[2]. Jyoti Shetty, Deepika Dash, Akshaya Kumar Joish, Guruprasad, "Review Paper on Web Frameworks, Databases and Web Stacks", 2020, International Research Journal of Engineering and Technology (IRJET), Apr 2020, e-ISSN: 2395-0056

[3]. Siddegowda C J, Gitu mani Borah, Chandru KA "react framework (creating a web application with react native)" .2018. International Journal of Recent Trends in Engineering \& Research Apr 2018 ISSN: 2455-1457

[4]. Парфьонов, Ю.Е. (2019). Managing user data of the web application for computer-based testing academic performance of the students. Системи обробки інформації. 129-133. 10.30748/soi.2019.157.18.

[5]. S.L. Kavya, Dr. S. Sarathambekai "Python Libraries and Packages for Web DevelopmentA Survey" .2019. International Journal of Innovative Research in Technology May 2019 ISSN: 2349-6002.

[6]. Prof. B Nithya Ramesh, Aashay R Amballi, Vivekananda Mahanta. "DJANGO THE PYTHON WEB FRAMEWORK" 2019 Department of Master of Computer Applications, NHCE, Bangalore, India May 2019.

[7]. Mohamed Abdalla Mokar, Sallam Osman Fageeri, Saif Eldin Fatton "Using Firebase Cloud Messaging to Control Mobile
Applications". 2019. Department of Information Technology Alazhari University, Sudan 2019.

\section{Cite this article as :}

Community Application", International Journal of Scientific Research in Computer Science, Engineering and Information Technology (IJSRCSEIT), ISSN : 2456-3307, Volume 7 Issue 3, pp. 37-43, May-June 2021. Available at doi : https://doi.org/10.32628/CSEIT21737 Journal URL : https://ijsrcseit.com/CSEIT21737 